\title{
How market orientation enhances business performance through value creation: Iranian commercial banks
}

\section{Hashem Aghazadeh, Emad Rahmanian* and Hassan Abolmolouki}

\author{
Faculty of Management, \\ University of Tehran, \\ 14155-6311, Tehran, Iran \\ Email: hagahzade@ut.ac.ir \\ Email: Emad.rahmanian@ut.ac.ir \\ Email: abolmolouki@ut.ac.ir \\ *Corresponding author
}

\begin{abstract}
The main purpose of this study firstly is to investigate the relation between market orientations and business performance in the Iranian context and secondly, to propose an indigenous model that explains the enhancement of business performance through market-oriented value creation. Findings suggest that in Iran, this relation is significant but is neglected and requires more attention. The methodology consists of two phases, model developing and model evaluation, and both are based on the views and comments of academic scholars and top managers. The findings confirm the mediative role of value creation both directly and indirectly. This study is the first study conducted in Iranian context developing a model representing the relation of mentioned factors in the Iranian banking sector, and its findings are based on the reality of this industry.
\end{abstract}

Keywords: market orientation; value creation; financial services; banking industry; emerging markets.

Reference to this paper should be made as follows: Aghazadeh, H., Rahmanian, E. and Abolmolouki, H. (2020) 'How market orientation enhances business performance through value creation: Iranian commercial banks', Int. J. Financial Services Management, Vol. 10, No. 1, pp.18-37.

Biographical notes: Hashem Aghazadeh is a Professor of Strategic Management and Marketing and Head of Business Management Department at the Faculty of Management, University of Tehran, Iran. His research focuses on business strategy and policy, parenting (holding) corporation strategy, strategic thinking, strategic marketing, market orientation. He has published distinguished articles in important journals also recently presented significant book in Palgrave McMillan titled Principles of Marketelogy.

Emad Rahmanian is a PhD Candidate and Research Assistant at the University of Tehran, Faculty of Management, Department of Marketing. His areas of research interest consist of consumer behaviour, consumer emotion, branding and organisational behaviour and diagnosis. His articles and papers have been presented at several conferences and published in journals. 
Hassan Abolmolouki is a $\mathrm{PhD}$ Candidate and Research Assistant at the Department of Business Management, University of Tehran, Iran. His research interests centre on strategic management, business policy, integrated marketing communication and organisational diagnosis. He is actively engaged in many consulting projects for leading companies and brands. His research has been presented at Islamic countries conferences and journals.

\section{Introduction}

The high intensity of competitive rivalry has dramatically affected the banking industry and scenery in recent years. In today's competitive marketplace, few companies can claim to offer a product or service so unique that it cannot be offered by other competitors. Additionally, customers expect seamless services and easily change their service provider in pursuit of better returns and services. So inevitably banks are seeking for retaining solutions that satisfy more-demanding less-loyal customers through superior performance and service quality. On the other hand, marketing scholars and practitioners have accepted the concept of market orientation as a major strategic shift to achieve success in a competitive environment. Unlike the past, nowadays high performance isn't just a winning card for service firms but it's essential for their survival and the key to success is a market and customer-oriented competitiveness.

The competitiveness of the financial services in such an environment is the focal point of this study. Different variables might contribute to the bank's competitiveness, variables such as national and international macro-environment, micro-environment, business context, and organisational characteristics, but market orientation is an outstanding facet that influences business competitiveness. In this study, we intend to investigate the relation between market orientation as a success factor and business performance as the desired outcome. To enrich the findings and considering the direct and indirect relationship between the two concepts, both aspects are investigated.

Market orientation is a context-specific subject and findings in other contexts are not completely generalisable to other countries and areas. However, the process in which market orientation results in enhanced performance can be studied in more detail with different approaches in different contexts (Kohli and Jaworski, 1990; Webster, 1993). Most studies addressing this subject are mainly in developed countries (see, e.g., Lee and Tsai, 2005; Keskin, 2006 and many more). Considering the lack of related empirical studies in the Iranian banking industry, the approach used in this study is more empirical to develop an indigenous model.

The findings on the outcome of market orientation in developed and developing countries seem to be mixed (Narver and Slater, 1990; Jaworski and Kohli, 1993; Perry and Shao, 2002; Dwairi et al., 2007). In other studies conducted in a similar context to Iran, the findings suggest that competitors' market orientation has the largest impacts on banks' performance through integration and coordination (Abu Dalbooh, 2014). Furthermore, Zaman et al. (2012) point out that in a similar context to Iran internal marketing would lead to market orientation and enhances performance through organisational commitment. Therefore, contextuality is a justification for this study. 
Studies on the effects of market orientation and business performance are not unprecedented in Iran. But their limited and general findings justify the necessity of this study. Furthermore, none of these studies provides an indigenous model. For example, Hassangholipour et al. (2012) point out that internal marketing and employing market orientation is neglected among Iranian financial institution (case study Melat bank in Tehran). In another study, Kheiri and Roshani (2013) studied the policy-making and business performance through marketing and market orientation (case study: Meli bank). The findings suggest that market orientation affects business performance through entrepreneurship.

Rezaee (2011), believes that the financial service industry is rapidly changing due to four main factors: 1) Economic condition, 2) Legal conditions, 3) Competitive condition, 4) Advanced technology. With the victory of the Islamic revolution in Iran (1979), all the Iranian private banks and financial firms were taken by the new government. The main consequence of this single governance was indifference towards service and products. However since 1997, again the Central Bank of Iran (CBI) announced its approval by establishing private banks. While the technological context of the financial industry was advancing incredibly, to survive, private banks and financial firms had no choice but to create competitive advantages by understanding their market and customer needs. Gradually single service entities in Iran are replaced by Full Packaged Service Holdings (FPSH) and this diversification is depending market orientation (Sepandarand et al., 2016).

To summarise, this study investigates and evaluates competitiveness, market orientation and the relation between them with a new approach to the concept in Iranian business context and also tries to fill the gap and lack of empirical studies in Iran by developing a model.

\section{Literature review}

\subsection{Market orientation}

In order to guarantee future competitiveness, financial services experience an increasing pressure to be more market-oriented. A critical part of any organisational marketing effort is to uncover how firms can develop and sustain a competitive advantage. Market orientation is an intangible organisational asset that is widely and globally proven to be a source of a competitive advantage that positively influences business performance (Narver and Slater, 1990; Jaworski and Kohli, 1993; Deshpande et al., 1993).

Market orientation, introduced by Narver and Slater (1990), is organisation-wide generation of market intelligence or information pertaining to current and future customer needs, dissemination of the information across departments, and organisationwide responsiveness to this information (Kohli and Jaworski, 1990) and formulating and implementation of strategies designed to respond to market accordingly. Hence, market orientation enables firms to deliver superior products and services to both internal and external customers. Therefore, market orientation intends to understand and capitalise exogenous environmental factors by identifying and responding to customers' need which makes market orientation an influential strategy in developing and sustaining competitive advantage through superior performance (Narver and Slater, 1990; Kohli and Jaworski, 1993; Kumar et al., 2011). 
Concerning the early debates about its philosophy, whether it is an organisational behaviour to exhibit or a process to follow, market orientation separated into two main schools, market orientation as a part of organisational culture and behaviour (Narver and Slater, 1990) and as processes (Kohli and Jaworski, 1990). The latter view argues that market orientation might be increased or decreased by internal organisational factors (Jaworski and Kohli, 1993). Since in this study value creations are considered a mediative factor through which market orientation can enhance business performance, the latter view is employed. According to Narver and Slater, market orientation has three behavioural components and two decision criteria: customer orientation, competitor orientation, and inter-functional coordination - a long term focus and a profit objective (Narver and Slater, 1990).

The role of market orientation applies to not only the external environment of the organization but also the internal environment and culture of an organisation (Lings, 2004). On the other hand, market orientation is a crucial factor in international and domestic markets (Cadogan and Diamatopoulos, 1995; Deshpande et al., 1993; GruberMuecke and Hofer, 2015). Concerning two main schools of market orientation, it is tried to choose factors comprehensively and encompassing.

Although the majority of early studies on market orientation and performance are set in the manufacturing sectors (McNaughton et al., 2002), the concept gradually gained popularity in the service domain.

Early prominent examples of market orientation consideration in the services sector include Greenley and Matcham (1986), and Qureshi (1993). Aside from early literature, there is growing string of research in service sector providing evidence from service sector, for example in franchising (Lee et al., 2015), in innovation in banking (Mahmoud, et al., 2016), market orientation, value and performance in hotel industry (PascualFernández et al., 2016). Interestingly, the results are two opposite poles, some scholars consider these effects to be positive (Deshpande and Farley, 1998; Matsuno et al., 2000; Slater and Narver, 2000). On the contrary, some scholars assert that these effects are negative or non-significant. For instance, researchers with roots in resource-based approaches (Grant, 1991, 1995) suggest that obtaining and sustaining a superior performance is an inward look resulting in focusing on internal capabilities rather than an outward look on customers. Although these negative findings are usually results of studyspecific reasons for the "anomalous" findings (McNaughton et al., 2002; Caruana et al., 1999). However, the relation between these two concepts is undeniable and needs a more in-depth investigation.

\subsection{Market orientation and business performance}

Although there is still an on-going debate on the dimensions of the market orientation construct (Lafferty and Hult, 2001), the relation between market orientation business performances is universally accepted (Sheth and Sisodia, 1999). Both schools of market orientation have confirmed the positive effect of market orientation on business performance. Narver and Slater (1990) argued that there is an association between market orientation and organisations' profitability. Also, Jaworski and Kohli (1993) examined the subject more broadly and pointed out that market orientation affects overall success in the market place. 
Chang et al. (1999) based on the findings of an extensive empirical study, argue that in services such as financial banking and healthcare sector in which a mutual interaction occurs, market orientation influences performance significantly. Additional findings from the different string of research also confirm this argument, for example, recent findings from cultural and behavioural studies (Morgan and Vorhies, 2018), and Japanese manufacturers firms (Takata, 2016) are in line with this argument.

In market-oriented growth, the role of intermediate and mediative variables is key. Market orientation approach provides a vehicle for a strategy that creates value for customers and consequently a sustainable competitive advantage which leads to superior performance (Jaworski and Kohli, 1993, Deshpande et al., 1993).

However, this role of value creation is unexplained or absent in much of the market orientation literature. There is evidence from the market-oriented business culture on the mediative role of factors between market orientation and business performance (e.g., Chang and Chen, 1998). Considering that there are several other potential variables unaccounted for, the effect of market orientation on business performance might be investigated more. This emphasises the importance of identification of mediative variables. Value creation is not a new concept.

\subsection{Value creation}

Considering the outbound nature of financial services, stakeholders' value-based approach is chosen as the mediative factor. In this approach, stakeholders are those individuals or groups which influence the organisation or are under influence by the organisation (Miller and Lewis, 1991). Grewal et al. (1998) argue that perceived value is separated into two categories: acquisition value and transaction value. In other studies, different scholars have studied the concept of the value and came up with several multidimensional approaches. For example, De Ruyter et al. (1997) formulated a comprehensive approach and categorised perceived value into two main categories: cognitive response and affective components.

Sweeney and Soutar (2001) asserted that value consists of three dimensions: functional value, social value, and emotional value. In another study, Sanchez et al. (2006) proposed six dimensions of perceived value consisting of a dimension of function value: installations, professionalism, quality and price; and an affective dimension: emotional value and social value.

To gain benefits from long-term loyalty and satisfaction of customers, commercial banks should focus on establishing and maintaining long-term relationships with their customers. Major changes in business models, fierce competition among financial organisations are among the most influential factors that forced Iranian banks to follow the market orientation. Reviewing financial banking literature indicates that financial banks should create and propose value in three areas: stakeholders' value, employees' value and value perceived by customers (Jacoby and Chestnut, 1978). Woodruff (1997) points out that creation and delivering value is the next source for competitive advantage for financial banks. In recent years Porter and Kramer (2019) noted that value creation is the only way to survive. 


\section{Methodology and research design}

The methodology consists of two phases. Phase one is modelling in which a conceptual model is developed and in the second phase, the developed model is evaluated by experts. Although during these phases, the evaluation of enhancement of customers' satisfaction was based on the analysis of the respected banks, bank managers used their monthly documents and evaluation to respond to the questions asked during modelling.

\subsection{Phase 1: Conceptual modelling}

Previously developed models in market orientation mostly have four main streams: dimensional models, models investigating antecedents and precedents of market orientation, models examining the relationship between market orientation and business performance and models of market orientation in the service context. After studying several models with different approaches, in order to come up with the elements of the model and narrowing down the factors, factors were classified by the causality: factors influencing market orientation and factors being influenced by market orientation.

Some of factors influencing market orientation are governmental policy and legislation (Hooley et al., 2001), technology (Olavarrieta and Friedman,1999), economy (Pels, 2002; Perry and Shao, 2002), customers (almost all studies), competitors (Dawes, 2000; Harrison-Walker, 2001), suppliers (Egan, 2001; Hernandez-Espalladora and ArcasLariob, 2003; Esteban et al., 2002), strategy (Olavarrieta and Friedmann, 1999; Harris and Ogbona, 2000; Kasper, 2002), culture (McCormack, 1999; Homburg and Pflesser, 2000; Trueman, 2004), employees (Harris, 1998). Also, factors being influenced by market orientation are customer loyalty (Lamb et al., 2010); customer satisfaction, financial performance, employee satisfaction (Gray, 1998) and long term development (Ruekert, 1992).

To summarise, these factors can be placed into five categories: precedents, market orientation, antecedents (meditator variables and performance), variables influencing the relation between market orientation and performance and finally variables parallel with market orientation.

Based on previous researches, the conceptual model is based on the theoretical relation between market orientation and business performance which is considered significant. This relation has been the focal point of many studies directly and indirectly. In this study, the indirect factor approach is studied through value creation. The questionnaire was designed to examine the factors discussed in the literature to identify each component's factors based on the comments and views of experts and managers.

Figure 1 Main components of proposed model without their respective factors

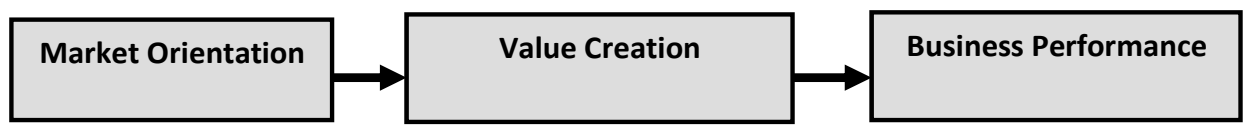


Financial organisations such as commercial banks that provide services for customers do not have a tangible product, therefore, must seek differentiation through value creation. In this model, it is tried to present a process in which market orientation approach through value creation can increase business performance.

In this part, the mixed method is used to create a model based on previously discussed literature to illustrate the relations between market orientation and business performance through value creation in commercial banks. It is tried to add several new components to existing models to contribute to the existing literature.

Considering data collection this study is a descriptive study using Structural Equation Modelling (SEM) techniques. After developing the conceptual model, the totality of the model was evaluated by the open-ended question and its components were questioned by close-ended questions. The expert panel was chosen among academic experts and practitioners are commercial and financial banks in Iran. Based on the results, the model was modified

\subsection{Population and sample}

The data collection was a two-phase process that was gathered from two populations. Most of the population was scholars, bank managers and high levels managers with a background in banking. Scholars were selected from different universities such as University of Tehran, Allame Tabatabae'i University, Chamran University, and other academic institutes. About 100 eligible respondents were identified and since the population is limited, to measure the sample, limited population formula was calculated as follows:

$$
n=\frac{N Z_{\alpha / 2}^{2} p q}{\varepsilon^{2}(N-1)+Z_{\alpha / 2}^{2} p q} \quad n=\frac{100 \times 1.96^{2} \times 0.5 \times 0.5}{0.065^{2} \times 99+1.96^{2} \times 0.5 \times 0.5} \cong 70
$$

Based on the calculation, the sample consists of 70 persons. Therefore, convenience sampling was used to gather the information. Eventually, 45 questionnaires were acceptable and were used. 30 correspondents were academic scholars and 15 were executive managers of banks.

\subsection{Data collection}

Selected experts were scattered geographically and due to the number of questions, questionnaire was selected as the tool for data gathering. Academic experts questionnaire included two parts; open-ended questions and Likert 5 closed questions while executive managers' questionnaire only employed closed questions. Questionnaires were disseminated by e-mail, fax and in some cases personally. $40 \%$ of the questionnaires were disseminated by e-mail. After three follow-ups and on the due date, 45 questionnaires were completed by respondents.

In order to evaluate the reliability of questionnaire, Cronbach's alpha test was used and the results show a satisfactory reliability. Alpha for experts' questionnaire is 0.9823 . The questionnaire presented to experts consisted of 48 in total. 30 questions were allocated to market orientation, 14 questions to value creation and four questions for 
performance. Also these results were satisfactory, alpha was 0.943 . The results for each section were $0.935,0.807$ and 0.782 , respectively.

\subsection{Data analysis}

The construct of each questionnaire is shown in Table 1. Also the methods and programs used to analyse the gathered data are presented in the Table 2.

Table 1 Construct of questionnaire

\begin{tabular}{llll}
\hline Questionnaire & Question types & Method & Software \\
\hline \multirow{2}{*}{ Experts } & Open questions & Content analysis & Excel \\
& & (Shannon Entropy) & \\
& Closed questions & $\bullet$ Binominal test & SPSS \\
& & - Friedman test & \\
Executive & $\bullet$ confirmatory and exploratory \\
managers & Closed questions & $\bullet$ Pactor analysis, 1st and 2nd order & Excel \\
& & $\bullet$ ANOVA test, One sample t-test & LISREL \\
\hline
\end{tabular}

The main questions of phase one regarding of the proposed model are summarised in Table 2. These questioned are based on the findings of other related research. The purpose of this phase is to answer these questions based on the results of analyses and provide a revised model with factors for further analysis.

Table 2 Methods and programs used to analyse the data

\begin{tabular}{|c|c|c|}
\hline software & method & Main question \\
\hline $\begin{array}{l}\text { Relation between market orientation and Business } \\
\text { Performance of Iranian financial banks } \\
\text { The indirect relation between market orientation and } \\
\text { Business Performance is more significant }\end{array}$ & $\begin{array}{l}\text { 1st and } 2 \text { nd order } \\
\text { confirmatory factor } \\
\text { analysis }\end{array}$ & LISREL \\
\hline $\begin{array}{l}\text { Business Performance includes factors such as business } \\
\text { performance towards market, business performance } \\
\text { towards customers, business performance towards } \\
\text { competitors, internal business performance } \\
\text { Market orientation consists of factors such as intelligent } \\
\text { culture and behaviour, strategic response and initiatives } \\
\text { coordinated systems and even controls }\end{array}$ & $\begin{array}{l}\text { 1st and } 2 \text { nd order } \\
\text { exploratory factor } \\
\text { analysis }\end{array}$ & SPSS \\
\hline $\begin{array}{l}\text { Value creation is a mediative factor between market } \\
\text { orientation and business performance }\end{array}$ & Path analysis & SPSS \\
\hline
\end{tabular}

Based on the findings of Shannon entropy test, experts have prioritised the factors of proposed model as follows: 
Table 3 Prioritisation of factors of proposed model

\begin{tabular}{|c|c|c|c|}
\hline component & Rank & Factor & Rank \\
\hline \multirow{4}{*}{$\begin{array}{l}\text { Business } \\
\text { performance }\end{array}$} & \multirow{4}{*}{1} & Organisation's internal performance & 1 \\
\hline & & Organisation's competitiveness & 2 \\
\hline & & Performance towards market & 3 \\
\hline & & Performance towards customer & 4 \\
\hline \multirow{3}{*}{$\begin{array}{l}\text { Market } \\
\text { orientation }\end{array}$} & \multirow{3}{*}{2} & Strategic response and initiatives & 1 \\
\hline & & Intelligent response and behaviour & 2 \\
\hline & & Coordinated departments and systems & 3 \\
\hline \multirow{4}{*}{ Value creation } & \multirow{4}{*}{3} & Organisation's internal value & 1 \\
\hline & & Organisation's value perceived by market & 2 \\
\hline & & Organisation's value perceived by customer & 3 \\
\hline & & Perceived competitive values & 4 \\
\hline
\end{tabular}

Also experts, based on binominal test and Friedman test, prioritised the independent and relative importance of the factors:

Table 4 Independent and relative importance of model's components and factors

\begin{tabular}{|c|c|c|c|c|c|}
\hline Component & $\begin{array}{l}\text { Independent } \\
\text { Importance }\end{array}$ & $\begin{array}{l}\text { Relative } \\
\text { Importance }\end{array}$ & Factor & $\begin{array}{l}\text { Independent } \\
\text { Importance }\end{array}$ & $\begin{array}{l}\text { Relative } \\
\text { Importance }\end{array}$ \\
\hline \multirow{3}{*}{$\begin{array}{l}\text { Market } \\
\text { orientation }\end{array}$} & \multirow{3}{*}{ Yes } & \multirow{3}{*}{ The same } & $\begin{array}{l}\text { Strategic response } \\
\text { and initiatives }\end{array}$ & Yes & 1 \\
\hline & & & $\begin{array}{l}\text { Intelligent response } \\
\text { and behaviour }\end{array}$ & Yes & 2 \\
\hline & & & $\begin{array}{l}\text { Coordinated } \\
\text { departments and } \\
\text { systems }\end{array}$ & Yes & 3 \\
\hline \multirow{4}{*}{$\begin{array}{l}\text { Value } \\
\text { creation }\end{array}$} & \multirow{4}{*}{ Yes } & \multirow{4}{*}{ The same } & $\begin{array}{l}\text { Organisation's } \\
\text { internal value }\end{array}$ & Yes & 1 \\
\hline & & & $\begin{array}{l}\text { Organisation's value } \\
\text { perceived by market }\end{array}$ & Yes & 2 \\
\hline & & & $\begin{array}{l}\text { Organisation's value } \\
\text { perceived by } \\
\text { customer }\end{array}$ & Yes & 3 \\
\hline & & & $\begin{array}{l}\text { Perceived } \\
\text { competitive values }\end{array}$ & yes & 4 \\
\hline \multirow{4}{*}{$\begin{array}{l}\text { Business } \\
\text { performance }\end{array}$} & \multirow{4}{*}{ Yes } & \multirow{4}{*}{ The same } & $\begin{array}{l}\text { Organisation's } \\
\text { internal performance }\end{array}$ & Yes & 1 \\
\hline & & & $\begin{array}{l}\text { Organisation's } \\
\text { competitiveness }\end{array}$ & yes & 2 \\
\hline & & & $\begin{array}{l}\text { Performance towards } \\
\text { market }\end{array}$ & Yes & 3 \\
\hline & & & $\begin{array}{l}\text { Performance towards } \\
\text { customer }\end{array}$ & yes & 4 \\
\hline
\end{tabular}




\subsection{Market orientation factor analysis}

1 First order confirmatory factor analysis: the goodness of fit indices are not satisfactory $\left(\chi^{2} / \mathrm{DF}=3.81\right.$, RMSEA $\left.>0.08\right)$ and suggest that this component needs modification. Also the results show that all the parameters are significant. Goodness of fit indices after modification are acceptable $\left(\chi^{2} / \mathrm{DF}<3, \mathrm{RMSEA}<0.08\right)$ and satisfactory.

2 Market orientation construct's inter-correlation: as expected there is a positive significant correlation between market orientation's factors. The highest correlation among factors is between implementation and control of strategic response and coordinated departments and systems.

3 Second order confirmatory factor analysis: analysing standard estimation of market orientations suggests that goodness of fit indices are below the mediocre $\left(\chi^{2} / \mathrm{DF}=4.01\right.$, RMSEA $\left.>0.08\right)$ and needs to be modified. The results for after modification are acceptable $\left(\chi^{2} / \mathrm{DF}<3, \mathrm{RMSEA}<0.065\right)$.

\subsection{Value creation factor analysis}

1 First order confirmatory factor analysis: here again the construct needs modification. After modification goodness of fit indices are satisfactory $\left(\chi^{2} / \mathrm{DF}<3\right.$, RMSEA $<0.08$ ).

2 Value creation construct's inter-correlation: the relation between value creation construct is positive and significant. The highest correlation is between organisational internal value and value and perceived competitive values and the least correlation is between perceived competitive values and value perceived by market.

3 Second order confirmatory factor analysis: the results for modified construct are as follows $\chi^{2} / \mathrm{DF}$ is greater than 3 and RMSEA is lesser than or equal to 0.08 . Among the factor explaining value creation construct, organisational internal value is the most significant (0.98).

\subsection{Business performance factor analysis}

1 First order confirmatory factor analysis (financial and non-financial): goodness of fit indices are acceptable $\left(\chi^{2} / \mathrm{DF}<3, \mathrm{RMSEA}<0.08\right)$. There is correlation between financial and non-financial factors $(0.39)$.

2 Second order confirmatory factor analysis: the indices are satisfactory and among the factors explaining the construct, financial performance is the most significant (0.67).

\subsection{Findings of phase 1}

After analysing the result and based on findings, the model was modified. Experts' comments on the proposed model and factors prioritised by them, made some minor changes in the model. The major assumptions of this paper were approved by the experts. 
a) There is a significant relation between market orientation and business performance of Iranian financial banks.

b) The indirect relation between market orientation and business performance is more significant and influential rather than direct relation.

c) Value creation is a mediative factor between market orientation and business performance.

Figure 2 Revised model based on the findings of phase one

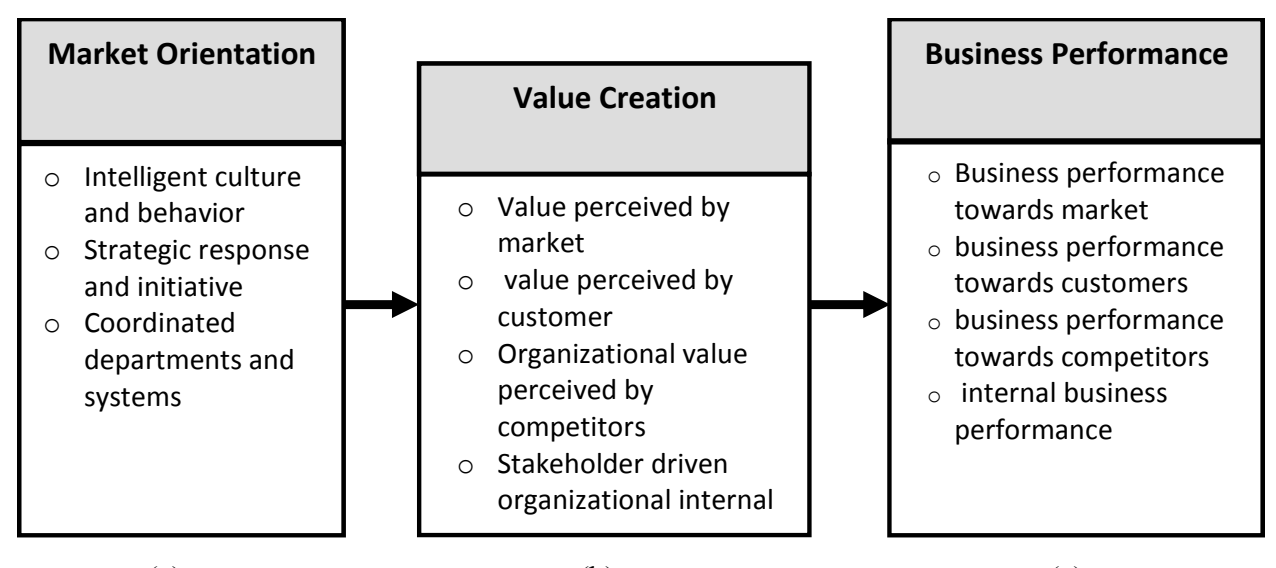

(a)

(b)

(c)

Path analysis was done to assess the quality of relation between market orientation and business performance. Findings are as follow:

1 The direct effects of market orientation on business performance: The results of the analysis of the first path suggest that market orientation effect on business performance is moderately low (path coefficient 0.28 ) while the coefficient between market orientation and value creation is 0.87 . Additionally, the coefficient between value creation and business performance is 0.60 .

2 The indirect effects of market orientation on business performance (through value creation): The results of second path analysis indicate that market orientation significantly influences on value creation (path coefficient 0.90 ) and consequently value creation has a high influence on business performance (0.87). Also, the indirect effect of market orientation on business performance is significant (0.78). The goodness of fit indices of the latter model is also more satisfactory and the mediative role of value creation in this model is confirmed.

The model developed in this phase is an eclectic model that identifies the factors of market orientation; value creation and business performance illustrate the quality of relation between these components. The model was evaluated by experts, both academic and executive; some modifications improved the model. The modified model of phase one is the basis of the second phase in which the modified model is investigated in more detail. 


\subsection{Findings of phase 2}

The conceptual model developed in the first phase of this paper represents the relation between market orientation and business performance in Iran. The aim of the second phase is to evaluate the developed model for final confirmation by the experts. In terms of data collection, this study is exploratory and descriptive using correlation. The developed model was again presented to the same experts of the previous phase and was analysed in a field survey form similar to that of phase one. The questionnaire consisted of two sections, open questions, and closed questions. First, the model was represented to the experts and their comments on the model were collected through open-end questions. In the second section of the questionnaire, the importance of components and factors were investigated. Collected data were analysed using content analysis (entropy test), binominal test and Friedman test.

Binominal hypotheses (independent importance of components and variables) are as follows:

- Null hypothesis: component: component is not important $H_{0}: p \leq 60 \%$

- Alternative hypothesis: component is important $H_{1}: p>60 \%$

Friedman test hypotheses (relative importance of components and variables) are as follows:

- Null hypothesis: component: components are of the same importance

- Alternative hypothesis: components are not of the same importance

\subsection{Findings of open end questionnaire}

In the open questionnaire, experts were asked about the conceptual model, components of the model and their relations. Based on the content analysis method, answers can be classified in four different areas and summarised as follows:

1 General comments: these comments are mostly on the totality and generalisation of the model. Experts approved the overall model generally and asserted that the organisation's value for other stakeholders such as shareholders and the performance of other stakeholders such as shareholders should be taken into account.

2 Comments on market orientation or first component of the model: On this component, it was mentioned that since some theories employ cultural views and some managerial views. Therefore, the mixed approach was considered. Also, it was necessary to differentiate between market orientation as an attitude (cultural approach), as a behaviour (behavioural approach) and as an organisational response. Other comments are summarised as:

- Intelligent behaviour: there is an overlap between market intelligence and customer intelligence, creation and disseminate of intelligence is the same coordinated departments and systems, in market orientation, intelligent behaviour and culture are two different concepts, instead of intelligent culture and behaviour, adaptive behaviour and culture (reflexive) toward environment must be employed. 
- Strategic response and initiative: Strategic thinking is better than strategic planning, using strategic analysis instead of identification of strategic response prerequisites.

- Coordinated systems and departments: they pointed out that this concept is vague and needs more clarification.

3 Comments on value creation, the second component of the model: Experts asserted that value creation should be considered as an outcome of the model and its components must be reduced. Another point is in that this model value creation is assumed the result of market orientation which is not always true; in some cases production orientation creates value. On model value perceived by the market, experts believed that it is better to investigate value perceived by distribution channel alongside other stakeholders' value perceived by the government. They also defined perceived organisational internal value as those values perceived by shareholders; on this component, they also added that the concept of organisational internal value is vague and ambiguous.

4 Comments on competitiveness or business performance: The main points mentioned by experts are as follows: the direct effect of market orientation on business performance, the mutual effects of components, differentiation of intelligent culture and behaviour, disambiguation of coordinated systems and departments, disambiguation of business internal value and finally disambiguation of bank's internal performance.

Concerning the content analysis approach, the next step is to investigate the comments. The main components of the proposed model are used to investigate the comments. Data are analysed using Shannon entropy technique and the results are presented in Table 5.

Table 5 The results of Shannon entropy for three main components of the model

\begin{tabular}{|c|c|c|c|c|c|c|c|c|c|}
\hline \multirow{2}{*}{ Variables } & \multicolumn{3}{|c|}{ Market orientation } & \multicolumn{3}{|c|}{ Value creation } & \multicolumn{3}{|c|}{ Performance } \\
\hline & $\begin{array}{l}\text { Raw } \\
\text { data }\end{array}$ & $\begin{array}{c}\text { Norm } \\
\text { data }\end{array}$ & coefficient & $\begin{array}{l}\text { Raw } \\
\text { data }\end{array}$ & $\begin{array}{l}\text { Norm } \\
\text { data }\end{array}$ & coefficient & $\begin{array}{l}\text { Raw } \\
\text { data }\end{array}$ & $\begin{array}{c}\text { Norm } \\
\text { data }\end{array}$ & coefficient \\
\hline Total & 14 & 1 & & 9 & 1 & & 12 & 1 & \\
\hline $\begin{array}{l}\text { Uncertainty } \\
\text { coefficient } E_{J}\end{array}$ & & & 0.642 & & & 0.632 & & & 0.662 \\
\hline $\begin{array}{l}\text { Importance } \\
\text { coefficient } W_{J}\end{array}$ & & & 0.183 & & & 0.181 & & & 0.189 \\
\hline Ranking & & & 2 & & & 3 & & & 1 \\
\hline $\begin{array}{l}\text { Number of } \\
\text { collected data }\end{array}$ & & & & & 25 & & & & \\
\hline
\end{tabular}

The Shannon entropy results for each component was analysed, as illustrated in Table 6, experts prioritise main components as presented: 
Table 6 Main components prioritised

\begin{tabular}{llcc}
\hline component & variable & Ranking & $\begin{array}{c}\text { Number of } \\
\text { collected data }\end{array}$ \\
\hline \multirow{3}{*}{$\begin{array}{l}\text { Value creation } \\
\text { component }\end{array}$} & Value perceived by market & 2 & \\
& value perceived by customer & 3 & 4 \\
& Competitive perceived value & 4 & \\
& Organisation's internal value & 1 & \\
\multirow{3}{*}{ Performance } & Business performance towards markets & 3 & 7 \\
& Business performance towards customers & 4 & \\
& Competitive business performance & 2 & \\
& business internal performance & 1 & \\
\hline \multirow{3}{*}{ Market orientation } & Intelligent behaviour and culture & 2 & \\
& Strategic initiative and response & 1 & \\
\hline
\end{tabular}

For the last component of the proposed model, experts ranked the factors accordingly: business internal performance, competitive business performance, business performance toward customers and towards market.

\subsection{Findings on components and factors}

Considering the nature of the second section's questions which are closed questions, in order to analyse the data, binominal test and Friedman test were used to evaluate respectively the independent and relative importance of the components and factors of the proposed model. These findings are presented in Table 7.

Table 7 Results on the main components of the model

\begin{tabular}{|c|c|c|}
\hline Components & $\begin{array}{c}\text { Binominal test } \\
\text { independent importance }\end{array}$ & $\begin{array}{l}\text { Friedman test } \\
\text { relative importance }\end{array}$ \\
\hline & important Not important & Not the same importance \\
\hline Market orientation & $\checkmark$ & $\checkmark$ \\
\hline Value creation & $\checkmark$ & $\checkmark$ \\
\hline Business performance & $\checkmark$ & $\checkmark$ \\
\hline
\end{tabular}

With the confidence level of $99 \%$, experts believe that market orientation, value creation and business performance are important significantly. Also these three components are of the same importance. All the factors of the model, with the confidence level of $99 \%$, are all important. The relative importance of mentioned factors is not the same and the ranking is presented in the tables. 
Table 8 Results on model's factors

\begin{tabular}{|c|c|c|c|c|c|}
\hline \multirow{2}{*}{ Components } & \multirow{2}{*}{ Factors (variable) } & \multicolumn{2}{|c|}{$\begin{array}{c}\text { Binominal test } \\
\text { independent importance }\end{array}$} & \multicolumn{2}{|c|}{$\begin{array}{l}\text { Friedman test } \\
\text { relative importance }\end{array}$} \\
\hline & & important & $\begin{array}{c}\text { Not } \\
\text { important }\end{array}$ & $\begin{array}{l}\text { Same } \\
\text { importance }\end{array}$ & $\begin{array}{l}\text { Not the same } \\
\text { importance }\end{array}$ \\
\hline \multirow{4}{*}{$\begin{array}{l}\text { Business } \\
\text { performance }\end{array}$} & Performance towards market & $\checkmark$ & & & 2 \\
\hline & $\begin{array}{l}\text { Performance towards } \\
\text { customer }\end{array}$ & $\checkmark$ & & & 1 \\
\hline & $\begin{array}{l}\text { Organisation's } \\
\text { competitiveness }\end{array}$ & $\checkmark$ & & & 3 \\
\hline & $\begin{array}{l}\text { Organisation's internal } \\
\text { performance }\end{array}$ & $\checkmark$ & & & 4 \\
\hline \multirow{4}{*}{$\begin{array}{l}\text { Value } \\
\text { creation }\end{array}$} & Value perceived by market & $\checkmark$ & & & 2 \\
\hline & value perceived by customer & $\checkmark$ & & & 1 \\
\hline & $\begin{array}{l}\text { Value perceived by } \\
\text { competitors }\end{array}$ & $\checkmark$ & & & 3 \\
\hline & Internal value & $\checkmark$ & & & 4 \\
\hline \multirow{3}{*}{$\begin{array}{l}\text { Market } \\
\text { orientation }\end{array}$} & $\begin{array}{l}\text { Intelligent behaviour and } \\
\text { culture }\end{array}$ & $\checkmark$ & & & 3 \\
\hline & $\begin{array}{l}\text { Strategic response } \\
\text { and initiative }\end{array}$ & $\checkmark$ & & & 1 \\
\hline & $\begin{array}{l}\text { Coordinated systems and } \\
\text { departments }\end{array}$ & $\checkmark$ & & & 2 \\
\hline
\end{tabular}

\section{Findings and discussion}

The objective of this study is to explore the role of market orientation business performance in financial services through value creation as a mediative variable and competitive strategy. We empirically provide evidence that market orientation and value creation are partly related, which in part enhances business performance. The aim of this study was twofold: first to show the relation between market orientation, value creation, and business performance. Second, to examine these relations and develop a model.

Although the importance of market orientation is widely accepted, in many domains it is often regarded as an operational concern rather a strategic issue to gain performance superiority. Another implication for the manager is that value creation plays a mediative role in the relation between market orientation and business performance. Baron and Kenny (1986) argue that to prove a mediating relation, for criteria must be met: 1) the independent variable is significant predictor of outcome variable, 2) the independent variable is significant predictor of mediator, 3 ) the mediator is a significant predictor of the outcome and 4) the direct relation of independent variable and outcome variable becomes significantly smaller with the addition of the mediator when compared to the direct relation of the independent variable to outcome variable without the mediator. This study proves that all these criteria are met and thus making value creation a mediative factor between market orientation and business performance. 
The main objective of this study was to develop a model of market orientation and business performance in the Iranian context. Considering the literature on the subject and previous models, a conceptual model was developed and experts' comments on the model were sought. The totality of the model was approved by the scholars of related fields. Based on banking experts' comments on the model, some revision was pointed out including taking into account the direct effect of market orientation on business performance, the mutual effects of components, differentiation between intelligent culture and behaviour and disambiguation of coordinated systems and departments, internal value of business and internal performance of the bank. The revised model is presented in Figure 3.

Figure 3 The final model of the study

\begin{tabular}{|c|c|c|c|c|}
\hline \multicolumn{2}{|c|}{$\begin{array}{c}\text { Market } \\
\text { Orientation }\end{array}$} & \multirow{2}{*}{\multicolumn{2}{|c|}{ Value Creation }} & $\begin{array}{c}\text { Business } \\
\text { Performance }\end{array}$ \\
\hline \multirow{2}{*}{\multicolumn{2}{|c|}{$\begin{array}{l}\text { Market oriented } \\
\text { culture } \\
\text { Intelligence } \\
\text { behavior } \\
\text { Strategic planning } \\
\text { and analyzing } \\
\circ \text { Efficient systems } \\
\text { of organization } \\
\text { Coordinated } \\
\text { departments }\end{array}$}} & & & \multirow{2}{*}{$\begin{array}{l}\text { Business performance } \\
\text { towards market } \\
\text { business performance } \\
\text { towards customers } \\
\text { business competition } \\
\text { performance } \\
\text { business internal } \\
\text { performance }\end{array}$} \\
\hline & & $\circ$ & $\begin{array}{l}\text { Value perceived by } \\
\text { market } \\
\text { value perceived by } \\
\text { customer } \\
\text { Organizational value } \\
\text { perceived by } \\
\text { competitors } \\
\text { organizational internal } \\
\text { value }\end{array}$ & \\
\hline
\end{tabular}

The article developed a model that investigated the effects of market orientation on business performance. The model tries to shed some light on this effect by making clear the process in which value creation strategies influences business performances. The study tries to present a positive empirical relation between market orientation and business performance through value creation.

The model highlights that the value creation benefits the organisation directly and indirectly. First, value creation enhances customer satisfaction through stakeholders driven strategies. The assessment of enhance in satisfaction is based on periodical assessment and evaluation carried out by the bank. Second, it increases business performances. Furthermore, the full implementation of the presented model as a strategic framework requires an inbound look in organisations since in the market orientation component most of the factors are internal. Furthermore, an inward-looking approach might be a good source value for outside shareholders.

\subsection{Managerial implications}

The findings of this study provide several important implications for managers. We noted that employing a market-oriented approach in organisation combined with a value creation perspective both are essential in gaining a superior performance. This is in line with those findings of Jaworski and Kohli (1993). 
The managerial implications for bank management are when developing new services or modifying the current one, managers must put customers at the centre of their activities and efforts. It was proved that bank superior performance is determined by the degree of market orientation. Also, findings encourage the manager to employ a proactive approach to the market instead of a reactive which emphasises on market orientation and results in market-oriented value creation.

Based on the findings of this study, managers must establish strategies that facilitated value creation through market orientation and develop structures and systems that can assist banks to put value creation at the core of every effort.

\subsection{Contribution, Limitation and direction for further researches}

Although this study is empirical, the proposed model has strong theoretical support and background, by providing an indigenous model. To this extent, this study contributes to the growing body of knowledge in service management. The proposed model extends our current understanding of the role of market orientation in financial services. The model also provides direction for financial managers and practitioners in terms of orienting their firms to a value-driven organisation and gaining a competitive advantage in the market.

The results of this study should be interpreted within its limitations. The main limitation of this study is potential bias in the sample. Also, the sample size might limit the results and findings. Furthermore, these limitations should be kept in mind for further research. Also, another limitation is that this study was self-administrated via emails. Interviews and personal meetings may provide more adequate and accurate information on the subject.

Despite all these limitations and shortcomings, this study tries to develop a model of market orientation in the financial banking industry which enhances our understandings of marketing of financial services. It can be concluded that by doing so this study adds to the literature of market orientation by providing empirical evidence. The manager also must align an internal view on value creation and market orientation with an outside view and nurture the organisational culture on these subjects.

Additional research in different countries and fields might be insightful on the subject. Researchers may employ this model and investigate it in other areas. Future studies might expand the outcome by including more exogenous variables such as strategic marketing. Finally, to overcome the limitations, sample size and data collection methods should be improved to develop a more comprehensive model.

\section{References}

Abu Dalbooh, M.A. (2014) 'The impact of market orientation on the performance of Islamic banks (case study: Jordanian Islamic banks)', International Journal of Engineering Research and Applications, Vol. 4, No. 1, pp.31-42.

Baron, R.M. and Kenny, D.A. (1986) 'The moderator-mediator variable distinction in social psychological research: conceptual, strategic, and statistical considerations', Journal of Personality and Social Psychology, Vol. 51, No. 6, pp.1173-1182.

Cadogan, J.W. and Diamatopoulos, A. (1995) 'Narver and Slater, Kohli and Jaworski and market orientation construct: integration and internationalization', Journal of Strategic Marketing, Vol. 3, No. 1, pp.41-60. 
Caruana, A., Pitt, L. and Berthon, P. (1999) 'Excellence-market orientation link: some consequences for service firms', Journal of Business Research, Vol. 44, pp.5-15.

Chang, T.Z. and Chen, S.J. (1998) 'Market orientation, service quality and business profitability: a conceptual model and empirical evidence', Journal of Services Marketing, Vol. 12, No. 4, pp.246-264.

Chang, T-Z., Mehta, R., Chen, S-J., Polsa, P. and Mazur, J. (1999) 'The effects of market orientation on effectiveness and efficiency: the case of automotive distribution channels in Finland and Poland', Journal of Services Marketing, Vol. 13, Nos. 4/5, pp.407-418.

Dawes, J. (2000) 'Market orientation and company profitability: further evidence incorporating longitudinal data', Australian Journal of Management, Vol. 25, No. 2, pp.173-199.

De Ruyter, K., Wetzels, M., Lemmink, J. and Mattson, J. (1997) 'The dynamics of the service delivery process: a value-based approach', International Journal of Research in Marketing, Vol. 14, No. 3, pp.231-243.

Deshpande, R., and Farley, J.U. (1998) 'Measuring market-orientation: generalization and synthesis', Journal of Market Focused Management, Vol. 2, No. 3, pp.213-232.

Deshpande, R., Farely, J.U. and Webster, E.F. Jr. (1993) 'Corporate culture, customer orientation and innovativeness in Japanese firms', Journal of Marketing, Vol. 57, No. 1, pp.23-27.

Dwairi, M., Bhuian, S. and Turkus, A. (2007) 'Revisiting the pioneering market orientation model in an emerging economy', European Journal of Marketing, Vol. 41, Nos. 7/8, pp.713-721.

Egan, J. (2001) 'What's in a name?', Proceedings of the Academy of Marketing Annual Conference, 2-4 July, University of Cardiff Business School.

Esteban, A. et al. (2002) 'Market orientation in service', European Journal of Marketing, Vol. 36, Nos. 9/10, pp.1003-1021.

Grant, R.M. (1991) 'The resource based theory of competitive advantage: implications for strategy formulation', California Management Review Spring, pp.114-135.

Grant, R.M. (1995) Contemporary Strategy Analysis, 2nd edition, Blackwell, Business, Cambridge, MA.

Gray, B. et al. (1998) 'Developing a better measure of market orientation', Europaen Journal of Marketing, Vol. 32, Nos. 9/10, pp.884-903.

Greenley, G.E. (1995) 'Market orientation and company performance: empirical evidence from UK companies', British Journal of Management, Vol. 6, pp.1-13.

Greenley, G.E. and Matcham, A.S. (1986) 'Marketing orientation in the service of incoming tourism', European Journal of Marketing, Vol. 20, No. 7, pp.64-73.

Grewal, D., Monroe, K.B. and Krishnan, R. (1998) 'The effect of price comparison advertising on buyers' perception of acquisition value, transaction value, and behavioral intention', Journal of Marketing, Vol. 62, pp.46-59.

Gruber-Muecke, T. and Hofer, K. (2015) 'Market orientation, entrepreneurial orientation and performance in emerging markets', International Journal of Emerging Markets, Vol. 10, No. 3, pp.560-571. Doi: 10.1108/IJoEM-05-2013-0076.

Harris, L. (1998) 'Cultural domination: the key to market-oriented culture?', European Journal of Marketing, Vol. 32, Nos. 3/4, pp.354-373.

Harris, L.C. and Ogbonna, E. (2000) 'The responses of front-line employees to MO culture change', European Journal of Marketing, Vol. 34, Nos. 3/4, pp.318-340.

Harrison-Walker, J.L. (2001) 'The measurement of a market orientation and its impact on business performance', Journal of Quality management, Vol. 6, pp.137-172.

Hassangholipour, T., Ansari, M., Elahi Gol, A. and Rahmani, H. (2012) 'The effect of internal marketing market orientation case study: meat bank', Modern Marketing Research Quarterly, Vol. 2, No. 4, pp.25-46.

Hernandez-Espalladora, M. and Arcas-Lario, N. (2003) 'The effects of authoritative mechanisms of coordination on market-orientation in asymmetrical channel partnerships', International Journal of Research in Marketing, Vol. 20, pp.133-152. 
Homburg, C. and Pflesser, C. (2000) 'A multiple-layer model of market-oriented organizational culture: Measurement issues and performance outcomes', Journal of Marketing Research, Vol. 37, No. 4, pp.449-462.

Hooley, G. et al. (2001) 'Market orientation in the service sector of the transition economies of central Europe', European Journal of Marketing, Vol. 37, Nos. 1/2, pp.86-106.

Jacoby, J. and Chestnut, R.W. (1978) Brand Loyalty Measurement and Management, John Wiley \& Sons, New York, NY.

Jaworski, B.J., and Kohli, A.K. (1993) 'Market-orientation: antecedents and Consequences', Journal of Marketing, Vol. 57, No. 3, pp.53-70.

Kasper, H. (2002) 'Culture and leadership in MO service organizations', European Journal of Marketing, Vol. 36, Nos. 9/10, pp.1047-1057.

Keskin, H. (2006) 'Market orientation, learning orientation, and innovation capabilities in SMEs: an extended model', European Journal of Innovation Management, Vol. 9, No. 4, pp.396-417.

Kheiri, B. and Roshani, A. (2013) 'Study of mediating role of marketing capabilities in strategy and business performance, case study Meli Bank', Management Quarterly, Vol. 10, No. 29.

Kohli, A.K. and Jaworski, B.J. (1990) 'Market orientation: the construct, research propositions, and managerial implications, Journal of Marketing, Vol. 54, pp.1-18.

Kumar, V., Jones, E., Venkatesan, R. and Leone, R.P. (2011) 'Is market orientation a source of sustainable competitive advantage or simply the cost of competing?', Journal of Marketing, Vol. 75, No. 1, pp.16-30.

Lafferty, B.A., Tomas, M. and Hult, G. (2001) 'A synthesis of contemporary market orientation perspectives', European Journal of Marketing, Vol. 35, Nos. 1/2, pp.92-109.

Lamb, C.W., Hair, J.F., McDaniel, C., Boshoff, C. and Terblanche, N.S. (2010) Marketing - South African, 4th edition, Cape Town, Oxford University Press, Southern Africa.

Lee, T.S. and Tsai, H.J. (2005) 'The effects of business operation mode on market orientation, learning orientation and innovativeness', Industrial Management and Data Systems, Vol. 105, No. 3, pp.325-348.

Lee, Y.K., Kim, S.H., Seo, M.K. and Hight, S.K. (2015) 'Market orientation and business performance: evidence from franchising industry', International Journal of Hospitality Management, Vol. 44, pp.28-37.

Lings, N.I. (2004) 'Internal market orientation-Construct and consequences', Journal of Business Research, Vol. 57, pp.405-413.

Mahmoud, M.A., Blankson, C., Owusu-Frimpong, N., Nwankwo, S. and Trang, T.P. (2016) 'Market orientation, learning orientation and business performance: the mediating role of innovation', International Journal of Bank Marketing, Vol. 34, No. 5, pp.623-648.

Matsuno, K., Mentzer, J.T. and Rentz, J.O. (2000) 'A refinement and validation of the MARKOR scale', Journal of the Academy of Marketing Science, Vol. 28, No. 4, pp.527-539.

McCormack, K.P. (1999) 'The Development of a Measure of Business Process Orientation', Paper presented at the European Institute for Advanced Studies in Management: Workshop on Organizational Design, Brussels, Belgium.

McNaughton, R.B., Osborne, P. and Imrie, B.C. (2002) 'Market-oriented value creation in service firms', European Journal of Marketing, Vol. 36, Nos. 9/10, pp.990-1002.

Miller, R.L. and Lewis, W.F. (1991) 'A stakeholder approach to marketing management using the value exchange models', European Journal of Marketing, Vol. 25, No. 8, pp.55-68.

Morgan, N.A. and Vorhies, D.W. (2018) 'The business performance outcomes of market orientation culture and behaviors', Innovation and Strategy, Vol. 15, pp.255-282.

Narver, J.C. and Slater, S.F. (1990) 'The effect of a market orientation on business profitability', Journal of Marketing, Vol. 54, pp.20-35. 
Olavarrieta, S. and Friedmann, R. (1999) 'Market-oriented culture, knowledge related resources, reputation assets and superior performance: a conceptual framework', Journal of Strategic Marketing, Vol. 7, pp.215-228.

Pascual-Fernández, P., López-Sánchez, J.Á., Reynoso, J. and Santos-Vijande, M.L. (2016) 'Innovativeness and market orientation as forerunners of the new service added value and performance in the hotel industry', Rediscovering the Essentiality of Marketing, Springer, Cham, pp.925-926.

Pels, P.P. (2000) 'Managerial understanding of contemporary industrial marketing issues', Qualitative Market Research: An International Journal, Vol. 5, No. 2, pp.135-143.

Perry, M.L., Shao, A.T. (2002) 'MO and incumbent performance in dynamic market', European Journal of Marketing, Vol. 36, Nos. 9/10, pp.1140-1153.

Porter, M.E. and Kramer, M.R. (2019) 'Creating shared value', Managing Sustainable Business, Springer, Dordrecht, pp.323-346.

Qureshi, S. (1993) 'Market driven public institutions attract resources', Journal of Professional Services Marketing, Vol. 9, No. 2, pp.83-92.

Rezaee, Z. (2011) Financial Services Firms: Governance, Regulations, Valuations, Mergers, and Acquisitions, Vol. 14, John Wiley \& Sons.

Ruekert, R.W. (1992) 'Developing market orientation: an organizational strategy perspective', International Journal of Research in Marketing, Vol. 9, pp.225-245.

Sanchez, J., Callarisa, L.L.J., Rodríguez, R.M. and Moliner, M.A. (2006) 'Perceived value of the purchase of a tourism product', Tourism Management, Vol. 27, No. 4, pp.394-409.

Sepandarand, S., Haghighi, K.M., Nasehifar, V. and Khasheie, V. (2016) 'Comparing the dimensions of banking business model in Iran with universal banking', Journal of Business Management (Management Knowledge), Vol. 8, No. 1, pp.73-88.

Sheth, J.N. and Sisodia, R.S. (1999) 'Revisiting marketing's law-like generalizations', Journal of the Academy of Marketing Science, Vol. 27, No. 1, pp.71-87.

Slater, S.F. and Narver, J.C. (2000) 'The positive effect of a market orientation on business profitability: a balanced replication', Journal of Business Research, Vol. 48, No. 1, pp.69-73.

Sweeney, J.C. and Soutar, G. (2001) 'Consumer perceived value: the development of multiple item scale', Journal of Retailing, Vol. 77, No. 2, pp.203-220.

Takata, H. (2016) 'Effects of industry forces, market orientation, and marketing capabilities on business performance: an empirical analysis of Japanese manufacturers from 2009 to 2011', Journal of Business Research, Vol. 69, No. 12, pp.5611-5619.

Trueman, K. (2004) 'Market-orientation and local government: barriers and constraints', Political Studies Association, pp.1-12.

Webster, C. (1993) 'Refinement of the marketing culture scale and the relationship between marketing culture and profitability of a service firm', Journal of Business Research, Vol. 26, No. 2, pp.111-131.

Woodruff, R.B. (1997) 'Customer value: the next source of competitive advantage', Journal of the Academy of Marketing Science, Vol. 25, No. 2, pp.139-153.

Zaman, K., Javid, N., Arshad, A. and Bibi, S. (2012) 'Impact of internal marketing on market orientation and business performance', International Journal of Business and Social Science, Vol. 3, No. 12, pp.76-87. 